Article

\title{
Enzyme Kinetics and Molecular Docking Studies on Cytochrome 2B6, 2C19, 2E1, and 3A4 Activities by Sauchinone
}

\author{
Eun Chae Gong ${ }^{1}$, Satya Chea ${ }^{1}$, Anand Balupuri ${ }^{2}$, Nam Sook Kang ${ }^{2}$, Young-Won Chin ${ }^{1}$ and \\ Young Hee Choi ${ }^{1 \text {,* }}$ \\ 1 College of Pharmacy and Intergrated Research Institute for Drug Development, Dongguk University-Seoul, \\ 32 Dongguk-lo, Ilsandong-gu, Goyang, Gyeonggi-do 10326, Korea; dmsco3901@hanmail.net (E.C.G.); \\ satyachea168@gmail.com (S.C.); f2744@dongguk.edu (Y.-W.C.) \\ 2 Graduate School of New Drug Discovery and Development, Chungnam National University, \\ Daejeon 305-764, Korea; balupuri@cnu.ac.kr (A.B.); nskang@cnu.ac.kr (N.S.K) \\ * Correspondence: choiyh@dongguk.edu; Tel.: +82-31-961-5212
}

Received: 8 February 2018; Accepted: 28 February 2018; Published: 2 March 2018

\begin{abstract}
Sauchinone, an active lignan isolated from the aerial parts of Saururus chinensis (Saururaceae), exhibits anti-inflammatory, anti-obesity, anti-hyperglycemic, and anti-hepatic steatosis effects. As herb-drug interaction (HDI) through cytochrome P450s (CYPs)-mediated metabolism limits clinical application of herbs and drugs in combination, this study sought to explore the enzyme kinetics of sauchinone towards CYP inhibition in in vitro human liver microsomes (HLMs) and in vivo mice studies and computational molecular docking analysis. In in vitro HLMs, sauchinone reversibly inhibited CYP2B6, 2C19, 2E1, and 3A4 activities in non-competitive modes, showing inhibition constant $\left(K_{\mathrm{i}}\right)$ values of $14.3,16.8,41.7$, and $6.84 \mu \mathrm{M}$, respectively. Also, sauchinone time-dependently inhibited CYP2B6, 2E1 and 3A4 activities in vitro HLMs. Molecular docking study showed that sauchinone could be bound to a few key amino acid residues in the active site of CYP2B6, 2C19, 2E1, and 3A4. When sibutramine, clopidogrel, or chlorzoxazone was co-administered with sauchinone to mice, the systemic exposure of each drug was increased compared to that without sauchinone, because sauchinone reduced the metabolic clearance of each drug. In conclusion, when sauchinone was co-treated with drugs metabolized via CYP2B6, 2C19, 2E1, or 3A4, sauchinone-drug interactions occurred because sauchinone inhibited the CYP-mediated metabolic activities.
\end{abstract}

Keywords: sauchinone; Saururus chinensis; CYP450; metabolic inhibition; herb-drug interaction; human liver microsome; docking

\section{Introduction}

Herb-drug combination therapies are widely used due to their therapeutic benefit, but risks of herb-drug interactions (HDIs) have also been reported [1-3]. Among various HDIs, attention should be paid to pharmacokinetic interactions between co-administered herbs and drugs, because such interactions could lead to altered therapeutic efficacies and/or toxicities [4,5]. Cytochrome P450 (CYP) enzymes possess broad substrate specificities to metabolize xenobiotics (almost $90 \%$ of drugs and herbs) and endogenous compounds [6-8]. Many clinical cases associated with CYP inhibition by herbs have been reported, including St. John's wort, ginko, milk thistle, cranberry, and garlic [7-12]. For example, concomitant administration of St. John's wort with protease inhibitors in antiretroviral therapies or warfarin has increased concentrations of protease inhibitors and warfarin via inhibiting CYP3A4 and 2C9, respectively, thus changing their efficacy and safety [13]. In these regards, evaluating CYP inhibition-mediated HDIs has been strongly recommended by the United States of America Food and Drug Administration (FDA) [14,15]. 
Saururus chinensis Hort. ex Loudon (Saururaceae), Sam-baek-cho in Korean, is a plant with a long history of medical use for treating beriberi, hyperlipidemia, fever, jaundice, edema, and inflammatory disease [16]. Sauchinone, a biologically active lignan isolated from the aerial parts of $S$. chinensis, also shows anti-oxidative, anti-inflammatory, hepatoprotective, anti-cardiovascular, anti-obesity, and anti-hepatic steatosis activities [17-22]. Recently, the approval of ESP-102 as a functional food containing sauchinone from S. chinensis (Daewoong Bio, South Korea; [17]) shows that $S$. chinensis can be developed as a source of functional food or herbal medicine in combination therapies [18-22]. As a major component of S. chinensis, sauchinone is extensively metabolized via CYPs and is highly distributed in the liver [23], suggesting that sauchinone-drug interaction may occur via CYP inhibition. However, up to date, there is no information about sauchinone-drug interaction through CYP inhibition. Therefore, the objective of this study was to explore the inhibitory effects of sauchinone on CYPs (CYP1A2, 2A6, 2B6, 2C9, 2C19, 2D6, 2E1, and 3A4) in in vitro human liver microsomes (HLMs) and determine pharmacokinetic interactions of sibutramine, clopidogrel, or chlorzoxazone (as representative drugs metabolized by CYP2B6, 2C19/3A4, and 2E1, respectively) with sauchinone in in vivo mice. In addition, computational molecular docking analysis was performed to understand how sauchinone interacted with particular CYPs (CYP2B6, 2C19, 2E1, and 3A4).

\section{Results}

\subsection{Reversible Inhibition (RI) of Sauchinone on CYP Activities in HLMs}

Results for RI of sauchinone and well-known reversible inhibitors of each CYP isoform (fluvoxamine, tranylcypromine, paroxetine, sulfaphenazole, omeprazole, quinidine, 4-methylpyrazole, and ketoconazole for CYP1A2, 2A6, 2B6, 2C9, 2C19, 2D6, 2E1, and 3A4, respectively) on CYP1A2, 2A6, 2B6, 2C9, 2C19, 2D6, 2E1, and 3A4 are shown in Figure 1. Their half maximal inhibitory concentration $\left(\mathrm{IC}_{50}\right)$ values were listed in Table 1 . When sauchinone concentrations were adjusted up to $300 \mu \mathrm{M}, \mathrm{IC}_{50}$ values of sauchinone on CYP2B6-catalyzed bupropion hydroxylation, 2C19-catalyzed $S$-mephenytoin hydroxylation, and 3A4-catalyzed testosterone hydroxylation were $0.458,3.60$, and $0.207 \mu \mathrm{M}$, respectively, which were lower than $5 \mu \mathrm{M}$. These $\mathrm{IC}_{50}$ values were close to those of their well-known direct inhibitors $(0.154,6.59,0.0845 \mu \mathrm{M}$ of paroxetine, omeprazole, and ketoconazole, respectively). Sauchinone also inhibited 2E1-catalyzed chlorzoxazone hydroxylation with $\mathrm{IC}_{50}$ of $35.4 \mu \mathrm{M}$, similar to that of 4-methylpyrazole $(35.8 \mu \mathrm{M})$, a well-known CYP2E1 inhibitor. The RI of sauchinone on other CYPs such as CYP1A2, 2A6, and 2D6 appeared to be negligible because $\mathrm{IC}_{50}$ values were over $300 \mu \mathrm{M}$.

Table 1. $\mathrm{IC}_{50}(\mu \mathrm{M})$ values of sauchinone and each well-known reversible inhibitor on respective CYP activity in HLMs.

\begin{tabular}{ccc}
\hline CYPs & Sauchinone $(\mu \mathbf{M})$ & Well-Known Inhibitor ${ }^{\text {a }}(\boldsymbol{\mu M})$ \\
\hline CYP1A2 & $>300$ & 0.0340 \\
CYP2A6 & $>300$ & 1.99 \\
CYP2B6 & $0.458 \pm 0.0932$ & 0.154 \\
CYP2C9 & $>300$ & 0.340 \\
CYP2C19 & $3.60 \pm 2.54$ & 6.59 \\
CYP2D6 & $>300$ & 0.0221 \\
CYP2E1 & $35.8 \pm 50.1$ & 0.519 \\
CYP3A4 & $0.207 \pm 0.193$ & 0.0845
\end{tabular}

a Fluvoxamine, tranylcypromine, paroxetine, sulfaphenazole, omeprazole, quinidine, 4-methylpyrazole, and ketoconazole are well-known inhibitors of CYP1A2, 2A6, 2B6, 2C9, 2C19, 2D6, 2E1, and 3A4 in RI mode, respectively. 


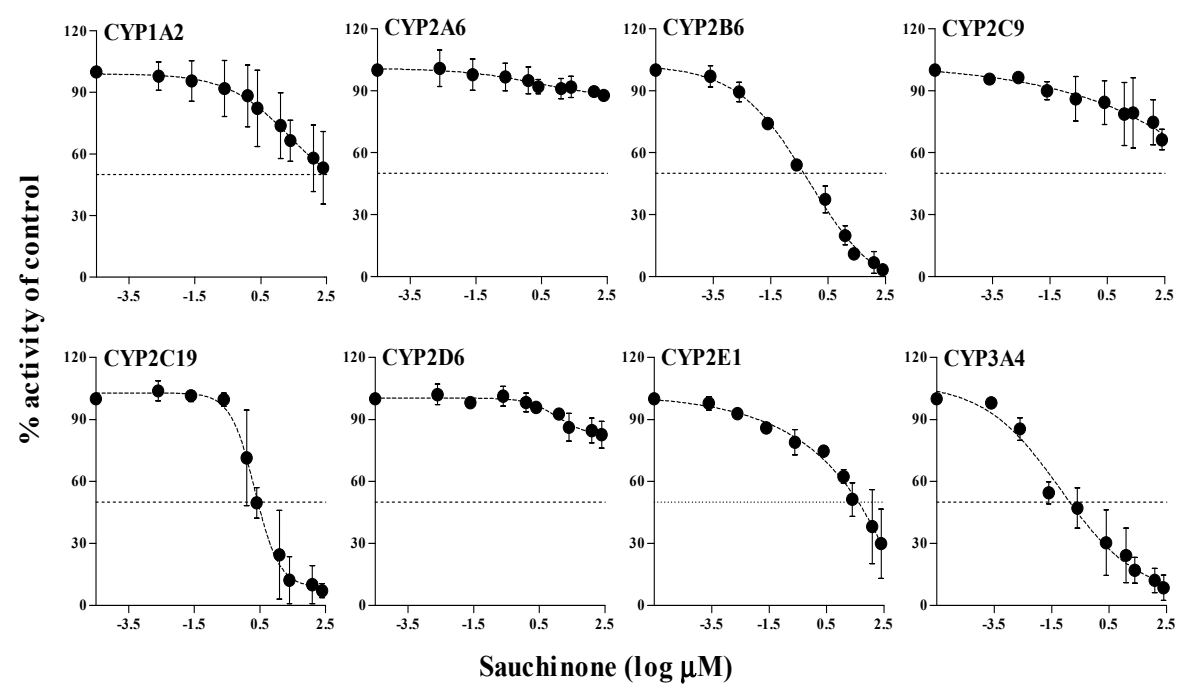

Figure 1. IC 50 curves of sauchinone for RI on CYP1A2, CYP2A6, CYP2B6, CYP2C9, CYP2C19, CYP2D6, CYP2E1, and CYP3A4 in HLMs. Y-axis is expressed as the remaining percentage of activity with sauchinone compared with the control (without sauchinone).

\subsection{Apparent Inhibition Constant $\left(K_{i}\right)$ Values of Sauchinone for CYP2B6, 2C19, 2E1, and $3 A 4$ in HLMs}

The enzyme kinetic assays on inhibition of CYP2B6, 2C19, 2E1, and 3A4 activities were conducted with various concentrations of sauchinone to characterize the type of RI based on the estimated $\mathrm{IC}_{50}$ values in RI (Table 1). As shown in Figure 2, all Dixon plots for the inhibition of CYP2B6, 2C19, 2E1, and $3 \mathrm{~A} 4$ by sauchinone were fitted well to the noncompetitive inhibition model in visual inspection and the $K_{i}$ values of sauchinone for CYP2B6, 2C19, 2E1, and 3A4 are 14.3, 16.8, 41.7, and $6.84 \mu \mathrm{M}$, respectively.
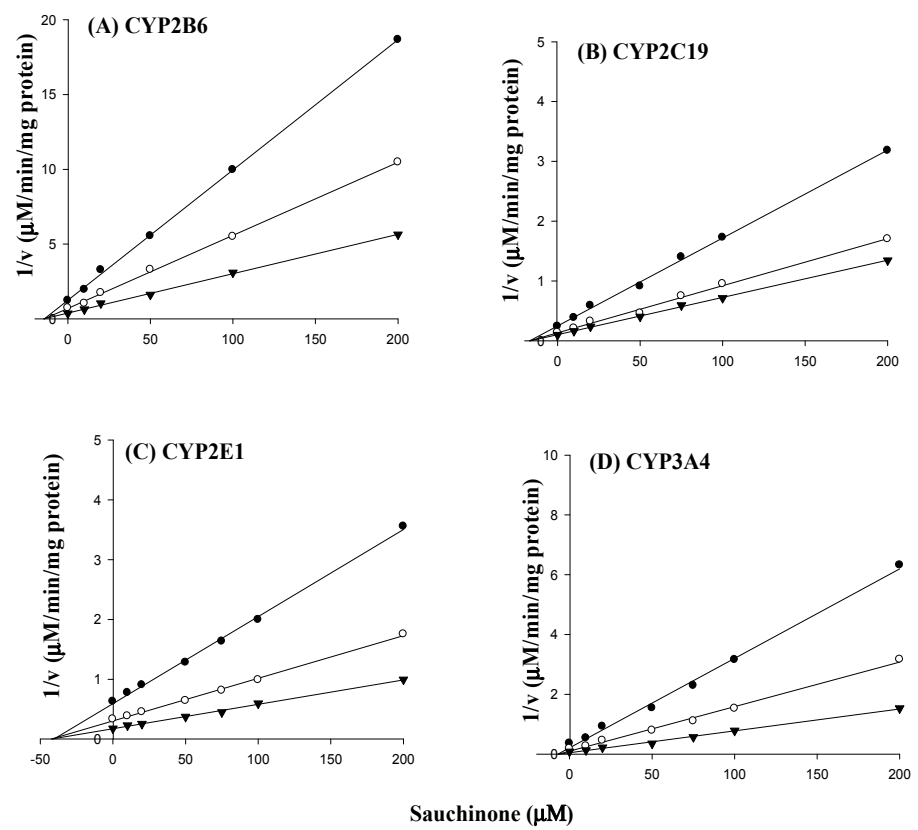

Figure 2. Dixon plots for inhibitory effects of sauchinone at various concentrations $(\bullet, 20 \mu \mathrm{M} ; \bigcirc, 50 \mu \mathrm{M}$;

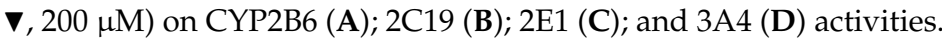

\subsection{Time-Dependent Inhibition (TDI) of Sauchinone on CYP Activities in HLMs}

After pre-incubating HLMs with sauchinone and $\beta$-nicotinamide adenine dinucleotide phosphate (NADPH) for $30 \mathrm{~min}$ as an inactivation step, inhibitory effects of sauchinone and well-known 
time-dependent inhibitors of each CYP isoform (furafylline, 8-methoxypsoralen, ticlopidine, tienilic acid, fluoxetine, paroxetine, disulfiram, and verapamil for CYP1A2, 2A6, 2B6, 2C9, 2C19, 2D6, 2E1, and 3A4, respectively) were examined. Results are shown in Figure 3 . Their $\mathrm{IC}_{50}$ values and $\mathrm{IC}_{50} \mathrm{shift}$ were also listed in Table 2. In our preliminary study to determine the incubation time of TDI, $30 \mathrm{~min}$ of inactivation incubation for HLM with an inhibitor reduced the activity of HLM. Therefore, a shorter incubation time $(10 \mathrm{~min})$ was selected for incubation after pre-incubation. By calculating $\mathrm{IC}_{50} \mathrm{shift}$ values of well-known time-dependent inhibitors, properties of inactivation incubation time of 30-min and incubation time for 10-min were verified. Sauchinone time-dependently inhibited CYP2B6, 2E1, and 3A4 with $\mathrm{IC}_{50}$ shifts in 30-min inactivation incubation of 9.28, 20.9, and 21.4-fold, respectively, compared to those without inactivation incubation. This indicated that sauchinone's metabolites formed in $30 \mathrm{~min}$ of pre-incubation time might have inhibitory effects on CYP2B6, 2E1, and 3A4. It has been reported that tentative metabolites of sauchinone are formed through CYPs in the liver [23]. However, sauchinone showed no apparent inhibition on other CYPs, with $\mathrm{IC}_{50}$ shift less than 2-fold.

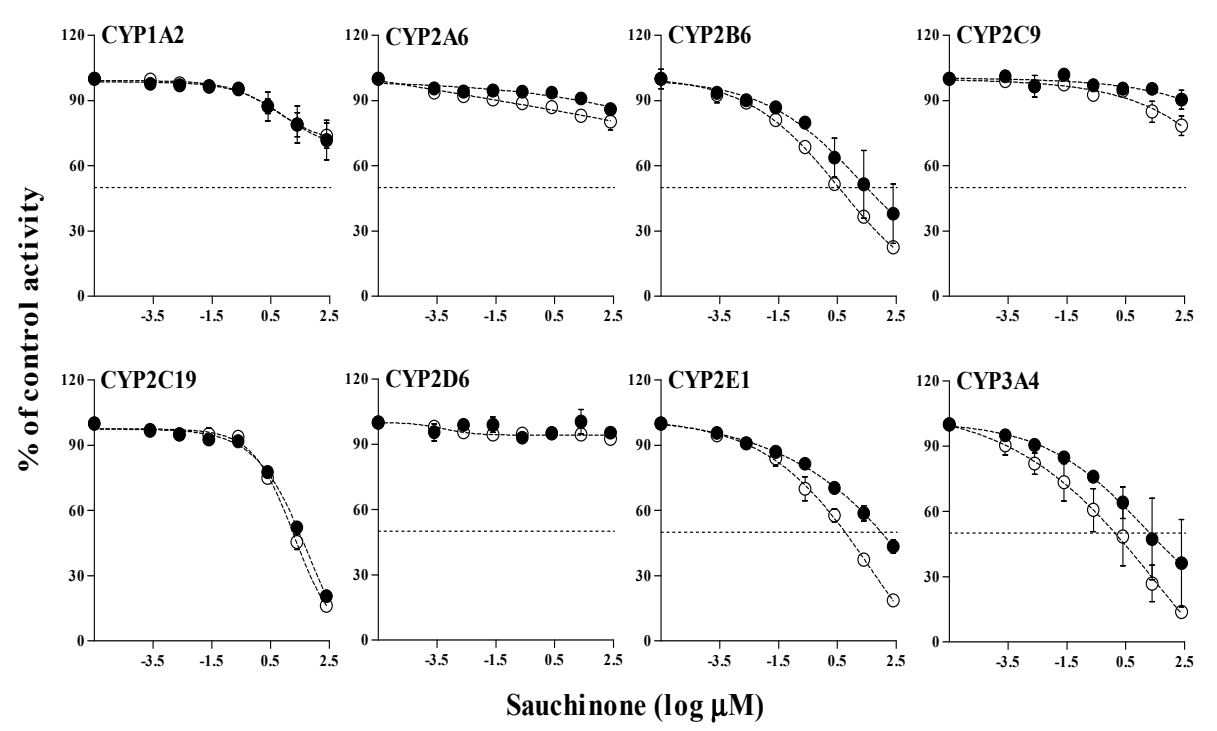

Figure 3. $\mathrm{IC}_{50}$ curves of sauchinone for TDI on CYP1A2, CYP2A6, CYP2B6, CYP2C9, CYP2C19, CYP2D6, CYP2E1, and CYP3A4 in HLMs. Y-axis is expressed as the remaining percentage of activity with sauchinone compared with the control (without sauchinone). Symbols of ' $\bullet$ ' and ' $\bigcirc$ ' represent 0 and 30-min inactivation incubation, respectively.

Table 2. $\mathrm{IC}_{50}(\mu \mathrm{M})$ values of sauchinone and each well-known reversible inhibitor on the respective CYP activity in HLMs. Also shown are the $\mathrm{IC}_{50}$ values and $\mathrm{IC}_{50}$ shifts of sauchinone and each well-known time-dependent inhibitor on each CYP's activity in HLMs.

\begin{tabular}{|c|c|c|c|c|c|c|}
\hline \multirow{3}{*}{ CYPs } & \multicolumn{3}{|c|}{ Sauchinone } & \multicolumn{3}{|c|}{ Well-Known Inhibitor a } \\
\hline & \multicolumn{2}{|c|}{$\mathrm{IC}_{50}(\mu \mathrm{M})$} & \multirow{2}{*}{ IC $_{50}$ Shift } & \multicolumn{2}{|c|}{$\mathrm{IC}_{50}(\mu \mathrm{M})$} & \multirow{2}{*}{ IC $_{50}$ Shift } \\
\hline & $0 \mathrm{~min}$ & $30 \mathrm{~min}$ & & $0 \mathrm{~min}$ & $30 \mathrm{~min}$ & \\
\hline CYP1A2 & $>300$ & $>300$ & - & 0.533 & 0.00424 & 126 \\
\hline CYP2A6 & $>300$ & $>300$ & - & 5.07 & 0.996 & 5.09 \\
\hline CYP2B6 & $36.4 \pm 27.0$ & $3.93 \pm 5.72$ & 9.28 & 0.529 & 0.0745 & 7.10 \\
\hline CYP2C9 & $>300$ & $>300$ & - & 50.7 & 0.157 & 323 \\
\hline CYP2C19 & $28.5 \pm 0.267$ & $19.4 \pm 2.92$ & 1.47 & 0.0312 & 0.00297 & 10.5 \\
\hline CYP2D6 & $>300$ & $>300$ & - & 2.59 & 0.288 & 8.99 \\
\hline CYP2E1 & $105 \pm 57.0$ & $5.04 \pm 1.91$ & 20.9 & 6.70 & 2.16 & 3.10 \\
\hline CYP3A4 & $24.5 \pm 51.3$ & $1.14 \pm 2.29$ & 21.4 & 20.3 & 1.61 & 8.41 \\
\hline
\end{tabular}

a Furafylline, 8-methoxypsoralen, ticlopidine, tienilic acid, fluoxetine, paroxetine, disulfiram, and verapamil are well-known inhibitors of CYP1A2, 2A6, 2B6, 2C9, 2C19, 2D6, 2E1, and 3A4 in TDI mode, respectively. 


\subsection{Molecular Docking Study}

Computational modeling of CYP and ligand interactions has gained a considerable amount of attention in recent years. Sauchinone was docked inside the active sites of human CYP3A4, CYP2B6, 2C19, and CYP2E1 to explore its binding mode and interactions.

For human CYP3A4, sauchinone showed a high binding energy of $-8.64 \mathrm{kcal} / \mathrm{mol}$ at the active site of CYP3A4 (PDB code: 3UA1). Docking results demonstrated that sauchinone was placed in the cavity enclosed by Phe57, Arg105, Arg106, Phe108, Phe215, Met371, Arg372, Leu373, Glu374, and Arg375. As shown in Figure 4A,B; Phe57, Arg105, Phe215, Met371, and Arg372 were involved in hydrophobic interactions with sauchinone, while Glu374 showed $\pi$-anion interaction with sauchinone. For human CYP2B6, sauchinone displayed a relatively low binding energy of $-8.47 \mathrm{kcal} / \mathrm{mol}$ at the active site of CYP2B6 (PDB code: 3IBD). Sauchinone was positioned in the binding pocket formed by Ile101, Ile114, Phe115, Phe297, Ala298, Glu301, Thr302, Leu363, Gly366, Val367, Pro368, and Val477. As shown in Figure 4C,D, Ile114, Phe297, Ala298, Val367, and Val477 demonstrated hydrophobic interactions with sauchinone, whereas Leu363 exhibited $\pi$-sigma interaction with sauchinone. In the case of human CYP2C19, sauchinone exhibited a much lower binding energy of $-7.76 \mathrm{kcal} / \mathrm{mol}$ at the active site of CYP2C19 (PDB code: 4GQS) than that for CYP2B6. Sauchinone was accommodated in the active site, surrounded by Val113, Phe114, Ile205, Asp293, Gly296, Glu300, Ile362, Ile366, and Phe476. As shown in Figure 4E,F, Val113, Phe114, Ile366, and Phe476 contributed to hydrophobic interactions with sauchinone, whereas Ile205 demonstrated $\pi$-sigma interaction with sauchinone. Sauchinone showed a very low binding energy of $-1.81 \mathrm{kcal} / \mathrm{mol}$ at the active site of CYP2E1 (PDB code: 3GPH). The binding pocket of sauchinone in CYP2E1 was composed of Ile115, Phe203, Phe207, Phe298, Ala299, Glu302, Thr303, Leu363, Val364, Leu368, Phe478, and Gly479. Hydrophobic interactions were merely responsible for the binding of sauchinone to CYP2E1. Active site residues such as Ile115, Phe207, Phe298, and Ala299 participated in hydrophobic interactions between CYP2E1 and sauchinone (Figure 4G,H).

(A)

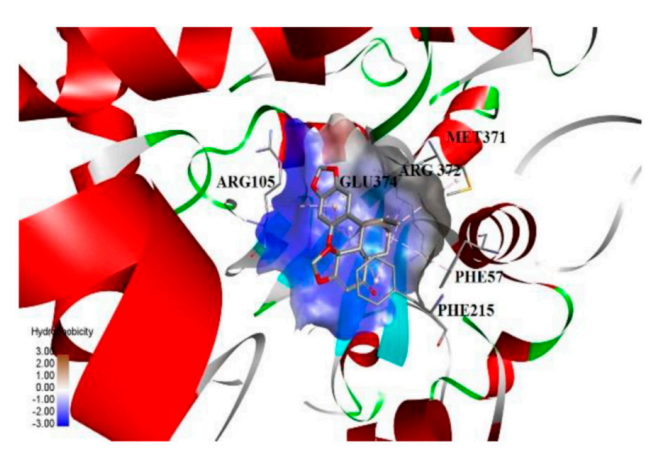

(C)

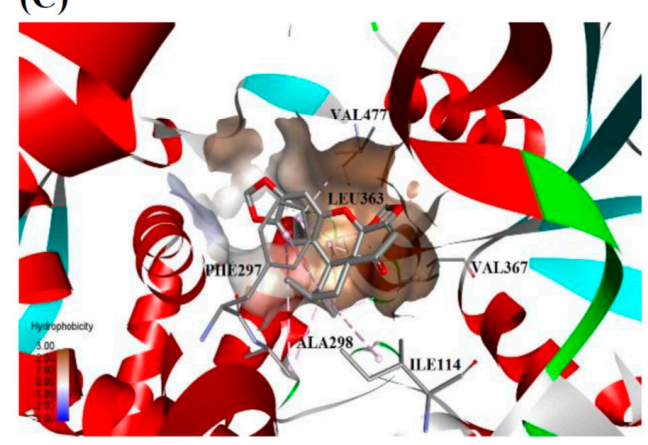

(B)

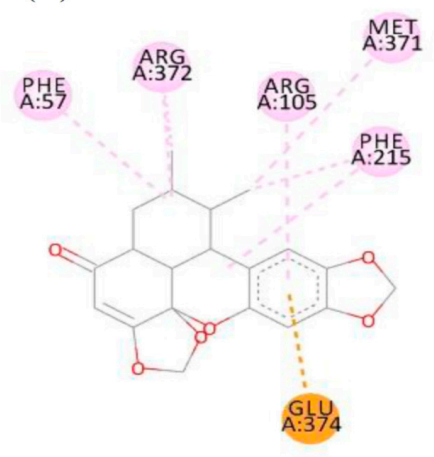

(D)

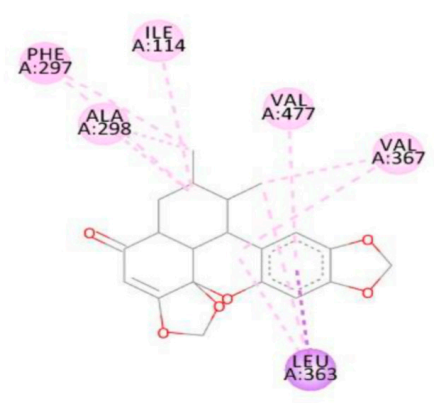

Figure 4. Cont. 
(E)

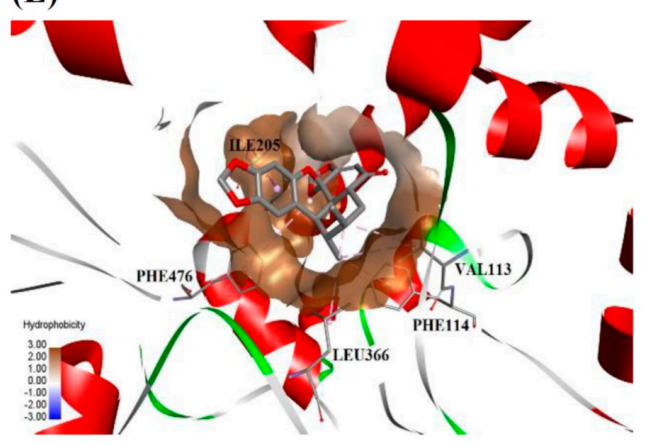

(G)

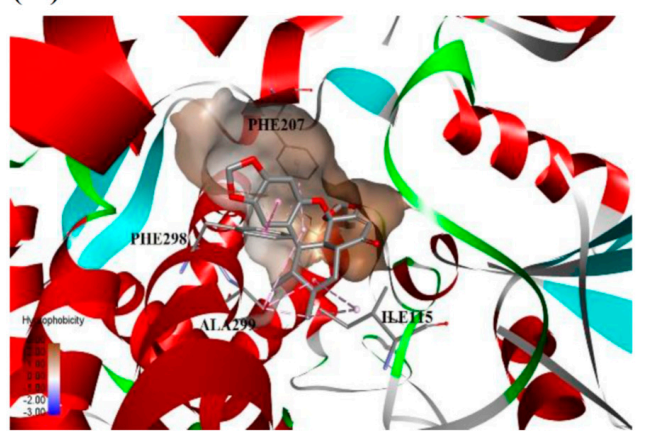

(F)

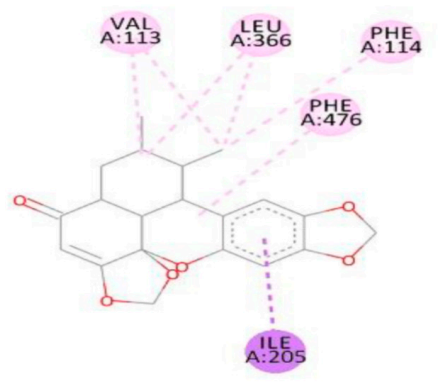

(H)

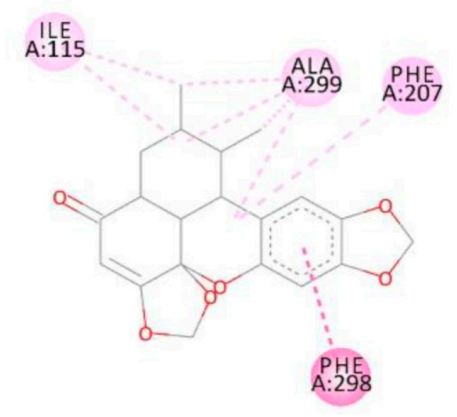

Figure 4. Molecular docking analysis demonstrating binding positions of sauchinone in human CYP3A4 (PDB code: 3UA1), CYP2B6 (PDB code: 3IBD), CYP2C19 (PDB code: 4GQS), and CYP2E1 (PDB code: $3 \mathrm{GPH})$. Three-dimensional illustrations show interactions of sauchinone with human CYP3A4 (A); 2B6 (C); 2C19 (E); and 2E1 (G) at labelled amino acid residues. Two-dimensional diagrams display interactions of sauchinone in the active sites of CYP3A4 (B); 2B6 (D); CYP2C19 (F); and 2E1 (H). Colors of dotted lines explain types of various interactions: hydrophobic (pink), $\pi$-anion (orange), and $\pi$-sigma (purple). For color in this figure, please see web version of this article.

\subsection{Drug Interactions between Sibutramine, Clopidogrel, or Chlorzoxazone and Sauchinone in Mice}

Pharmacokinetic interactions between sauchinone and drugs mainly metabolized by CYP2B6, 2C19, 2E1, and/or 3A4 were evaluated in vivo using mice. Sibutramine, clopidogrel, and chlorzoxazone were chosen as representative drugs mainly metabolized by CYP2B6, CYP2C19/3A4, and CYP2E1 [24-26] to provide examples of sauchinone and drug interactions through CYP2B6, CYP2C19/3A4, and CYP2E1 inhibitions to be consistent with in vitro results. Moreover, a combination of sibutramine or clopidogrel with herbal supplements or foods having activities against metabolic disorders have been frequently reported $[25,26]$. After oral administration of sibutramine, clopidogrel, or chlorzoxazone with sauchinone to mice, the mean arterial plasma concentration-time profiles of sibutramine, clopidogrel, or chlorzoxazone were determined. Results are shown in Figure 5 and their relevant pharmacokinetic parameters are listed in Table 3. In mice receiving oral administration of sibutramine and sauchinone together, the area under the plasma concentration-time curve from time zero to the last measured time to infinity (AUC), peak plasma concentration $\left(C_{\max }\right)$, terminal half-life $\left(\mathrm{t}_{1 / 2}\right)$, and clearance/ absolute bioavailability $(\mathrm{CL} / F)$ of sibutramine were significantly greater (by 23.6\%), higher (by 41.5\%), smaller (by 16.2\%), and slower (by 19.0\%), respectively, than those in mice receiving sibutramine alone. Similarly, AUC, $C_{\max }, \mathrm{t}_{1 / 2}$, and CL/F of clopidogrel in mice receiving clopidogrel and sauchinone together were significantly greater (by 31.0\%), higher (by 17.3\%), smaller (by 19.1\%), and slower (by 24.7\%), respectively, than those in mice receiving clopidogrel alone. In mice co-administered with chlorzoxazone and sauchinone together, $\mathrm{AUC}, C_{\max }, \mathrm{t}_{1 / 2}, \mathrm{CL} / F$, and time to reach $C_{\max }\left(T_{\max }\right.$ ) of chlorzoxazone were significantly greater (by $61.1 \%$ ), higher (by $40.6 \%$ ), 
smaller (by 9.36\%), slower (by 38.0\%), and greater (by 50.0\%), respectively, than those in mice receiving chlorzoxazone alone.
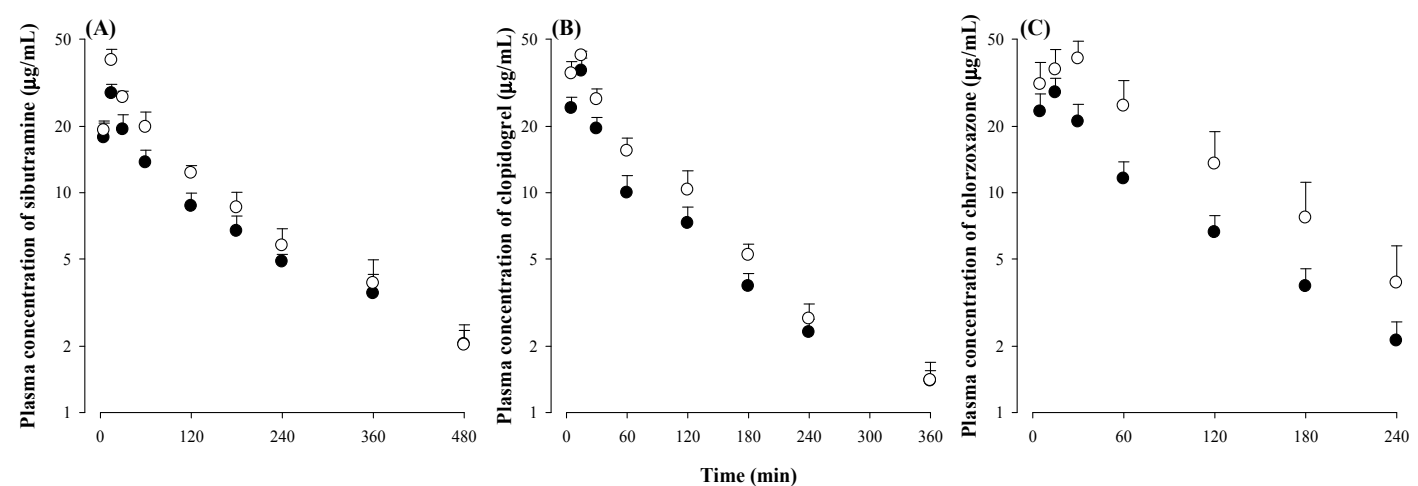

Figure 5. Plasma concentrations of sibutramine (A); clopidogrel (B); or chlorzoxazone (C) after its oral administration with vehicle $(\bullet)$ and sauchinone $(\bigcirc)$. The number of mice were five for each group.

Table 3. Pharmacokinetic parameters of sibutramine, clopidogrel, or chlorzoxazone after its oral administration with or without sauchinone.

\begin{tabular}{cccc}
\hline Parameters & Sibutramine & Clopidogrel & Chlorzoxazone \\
\hline Without sauchinone & $(n=5)$ & $(n=5)$ & $(n=5)$ \\
AUC $(\mu \mathrm{g} \mathrm{min} / \mathrm{mL})$ & $3980 \pm 308$ & $2680 \pm 372$ & $2390 \pm 446$ \\
$C_{\max }(\mu \mathrm{g} / \mathrm{mL})$ & $28.2 \pm 2.86$ & $35.8 \pm 5.21$ & $28.8 \pm 4.76$ \\
$T_{\max }(\mathrm{min})$ & $15.0(15.0-15.0)$ & $15.0(15.0-15.0)$ & $15.0(5.00-15.0)$ \\
$\mathrm{t}_{1 / 2}(\mathrm{~min})$ & $197 \pm 35.9$ & $131 \pm 6.70$ & $73.7 \pm 6.34$ \\
$\mathrm{CL} / F(\mathrm{~mL} / \mathrm{min} / \mathrm{kg})$ & $0.253 \pm 0.0208$ & $3.81 \pm 0.514$ & $4.37 \pm 0.972$ \\
With sauchinone & $(n=5)$ & $(n=5)$ & $(n=5)$ \\
$\mathrm{AUC}(\mu \mathrm{g} \min / \mathrm{mL})$ & $4920 \pm 415^{\mathrm{a}}$ & $3510 \pm 288^{\mathrm{a}}$ & $3850 \pm 880^{\mathrm{a}}$ \\
$C_{\max }(\mu \mathrm{g} / \mathrm{mL})$ & $39.9 \pm 4.97^{\mathrm{a}}$ & $42.0 \pm 2.33^{\mathrm{a}}$ & $40.5 \pm 6.55^{\mathrm{a}}$ \\
$T_{\max }(\mathrm{min})$ & $15.0(15.0-15.0)$ & $15.0(15.0-15.0)$ & $30.0(15.0-30.0)^{\mathrm{a}}$ \\
$\mathrm{t}_{1 / 2}(\mathrm{~min})$ & $165 \pm 31.8$ & $106 \pm 25.6$ & $66.8 \pm 7.99^{a}$ \\
$\mathrm{CL} / F(\mathrm{~mL} / \mathrm{min} / \mathrm{kg})$ & $0.205 \pm 0.0186^{\mathrm{a}}$ & $2.87 \pm 0.225^{\mathrm{a}}$ & $2.71 \pm 0.519^{\mathrm{a}}$ \\
\hline
\end{tabular}

$\mathrm{AUC}$, area under the plasma concentration-time curve from time zero to the last measured time to infinity; $C_{\max }$, peak plasma concentration; $T_{\max }$, time to reach $C_{\max } ; \mathrm{t}_{1 / 2}$, terminal half-life; $\mathrm{CL} / F$, clearance/absolute bioavailability.; ${ }^{a}$ Significantly different $(p<0.05)$ compared with that without sauchinone.

\section{Discussion}

CYP3A4 followed by CYP2B6, 2C9, 2D6, 2C19, 2E1, 1A2, and 2A6 in sequence are still considered as the main metabolic pathways in CYP-mediated metabolic interactions, although new allelic forms of CYPs have been identified $[15,27,28]$. Therefore, we investigated the inhibitory effects of sauchinone on eight CYP isoforms using a cocktail probe assay in HLMs to understand potential sauchinone-drug interactions.

CYP inhibitions can be classified into RI and TDI of CYP activities [6,14,29]. RI occurs when an enzyme inhibits itself rapidly and reversibly inhibits CYP activities via rapid association and dissociation between inhibitors and CYPs. On the other hand, TDI occurs in a relatively delayed and irreversible mode through irreversible covalent binding or quasi-irreversible non-covalent tight binding of an inhibitor itself and/or its metabolites with CYPs [14,30]. TDI displays a prolonged onset of inhibition and persists even after an inhibitor is eliminated. Therefore, there is a time gap between the occurrence or disappearance of inhibition and inhibitor exposure in TDI $[14,28,30]$. One reason might be auto-inhibition of an inhibitor. Auto-inhibition of an inhibitor means that the metabolism of an inhibitor itself becomes slow and the inhibitor itself is present in the body longer [30]. Another reason is that TDI happens after the metabolites of an inhibitor are formed, not when an inhibitor itself 
is exposed [6] because an inhibitor is metabolized to a reactive intermediate which can inactivate CYPs by covalent binding [30]. TDI can bring slow-onset, cumulative, and long-lasting interaction. Therefore, evaluation of TDI is necessary to estimate the risk of adverse effects associated with inhibition of CYPs. Actually, long-term intakes of herbs tend to cause TDI which can display late inhibition of metabolic enzymes. Cases of TDI such as plumbagin, silybin, and extract of Cassia abbreviata have been reported in HDIs [27,31,32]. Particularly high dose administration of herbs (e.g., g unit of administered herbs) can easily inhibit CYPs. Repeated long-term use of herbs may cause irreversible or quasi-irreversible binding to CYPs, leading to TDI-mediated HDIs [33]. Thus, the inhibitory effects of sauchinone on CYPs are explored in RI and TDI together using in vitro assays.

As shown in Table 1, sauchinone strongly inhibited CYP3A4 > 2B6 > 2C19 in sequence and moderately inhibited CYP2E1. There was negligible change in metabolic rate with increasing sauchinone concentrations up to $300 \mu \mathrm{M}$ (our unpublished data). This could be due to saturation of the enzyme. To predict $\mathrm{IC}_{50}$ values of sauchinone for the inhibition of $\mathrm{CYP}$ activities via graphing, up to $300 \mu \mathrm{M}$ of sauchinone was used because sauchinone concentrations used in in vitro can be different from in vivo physiological levels. Hence, the pharmacokinetic interaction of sauchinone with drugs in vivo were necessary to conduct considering physiological levels of sauchinone.

To explore how CYP enzymes interacted with their substrates and inhibitors, inhibition kinetic studies were performed. As shown in Figure 2, sauchinone inhibited CYP2B6, 2C19, 2E1, and 3A4 in non-competitive manners, similar to results obtained from RI. The difference between $\mathrm{IC}_{50}$ and $K_{i}$ values could be due to different experimental conditions such as incubation time, concentrations of substrate and sauchinone, and protein amounts. However, the order of inhibitory effect of sauchinone on CYP isoforms was the same: sauchinone strongly inhibited CYP3A4 $>2 B 6 \fallingdotseq 2 C 19$ and moderately inhibited CYP2E1. Non-competitive inhibition by sauchinone of CYP2B6, 2C19, 2E1, and 3A4 indicated that sauchinone might be able to reduce the activities of CYP2B6, 2C19, 2E1, and 3A4 by binding to an allosteric site of the CYPs without interfering with binding of a substrate to the active site of the CYP. As a result, metabolic clearance of a substrate was decelerated due to the inhibiting effect of sauchinone, similar to results of a previous report [3].

Interestingly, metabolites of sauchinone via oxidation, di-oxidation, methylation, demethylation, dehydrogeneation, or bis-glucuronidation in S9 fractions of liver and intestine have already been reported [23]. These results suggest that the CYP-mediated metabolic pathway of sauchinone might intervene in CYP activities, leading to auto-inhibition of sauchinone and/or reduction of metabolism of co-administered drugs through CYPs. Metabolites of sauchinone formed through CYPs can also interact with CYPs, causing sauchinone-drug interaction in a TDI manner. In this study, sauchinone time-dependently inhibited CYP2B6, 2E1, and 3A4 based on the shift of $\mathrm{IC}_{50}$ values, as shown in Table 2.

To further understand interactions between sauchinone and CYP2B6, 2C19, 2E1, or 3A4, molecular docking analysis was performed. Sauchinone showed the highest binding energy $(-8.64 \mathrm{kcal} / \mathrm{mol})$ at the active site of CYP3A4 with the lowest $K_{\mathrm{i}}(6.84 \mu \mathrm{M})$ against CYP3A4 among four CYPs (CYP2B6, 2C19, 2E1, and 3A4). Simulation results of the present study predicted that Phe57, Arg105, Phe215, Met371, Arg372, and Glu374 were critical residues for the binding of sauchinone to CYP3A4 (Figure 4A,B). These interactions might be accountable for the high and better inhibitory activity of sauchinone against human CYP3A4 as compared to that against human CYP2B6, CYP2C19, or CYP2E1. Previous studies have reported that Phe57, Arg105, Phe215, Arg372, and Glu374 are responsible for ligand binding in CYP3A4 [4,34-37]. Against human CYP2B6, relatively lower binding energy of $-8.47 \mathrm{kcal} / \mathrm{mol}$ at the active site of CYP2B6 matched with the slightly lower inhibition $\left(K_{i}=14.30 \mu \mathrm{M}\right)$ compared to CYP3A4. Residues Ile114, Leu363, Phe297, Ala298, Val367, and Val477 were found to be important residues for the binding of sauchinone to human CYP2B6 (Figure 4C,D), consistent with prior research studies suggesting that Ile114, Phe297, Ala298, Leu363, Val367, and Val477 might play important roles in ligand recognition by CYP2B6 [38-40]. In the case of human CYP2C19, sauchinone showed a lower binding energy of $-7.76 \mathrm{kcal} / \mathrm{mol}$ at the active site, consistent with low inhibition for 
CYP2C19 $\left(K_{i}=16.80 \mu \mathrm{M}\right)$ compared to that for CYP2B6 or 3A4. As shown in Figure 4E,F, Val113, Phe114, Ile205, Ile366, and Phe476 were important for the interactions between sauchinone and CYP2C19. It has been reported that Val113, Phe114, Ile205, Ile366, and Phe476 are crucial residues for ligand binding in CYP2C19 [41,42]. Sauchinone exhibited the lowest binding energy of $-1.81 \mathrm{kcal} / \mathrm{mol}$ at the active site of CYP2E1, consistent with its least inhibition against human CYP2E1 $\left(K_{i}=41.70 \mu \mathrm{M}\right)$. Active site residues Ile115, Phe207, Phe298, and Ala299 participated in hydrophobic interactions with sauchinone (Figure 4G,H) in agreement with previous studies reporting that Ile115, Phe207, Phe298, and Ala299 are responsible for ligand binding to CYP2E1 [43-45]. These results provided valuable information on structure-activity relationships between sauchinone and CYP2B6, 2C19, 2E1, and 3A4.

$\mathrm{RI}$ and TDI-mediated metabolic inhibition by herbs in vitro system has been accepted as a useful approach to predict changes in efficacy and toxicity of co-administered drug(s) [46]. However, inhibitory effects of herbs predicted from $\mathrm{IC}_{50}$ and $K_{i}$ values in in vitro experiments are insufficient to support in vivo results (especially at clinical levels) because various metabolic pathways and other elements besides metabolic inhibition can manage HDIs in in vivo. For example, discrepancies in HDI between in vitro and clinical results have been reported in cases of milk thistle or Panax ginseng with drugs $[9,46]$. Investigation on HDIs in humans can draw the most accurate conclusion to explain changes in efficacy or adverse reactions to co-administered drugs. However, evaluating HDI at the clinical level has risk of serious HDIs. Hence, prediction of HDIs at preclinical levels has been adopted to identify potential HDIs and underlying mechanisms along with in vitro results [9,47].

In in vivo systems, pharmacokinetic parameters such as AUC and $C_{\max }$ are used as the main endpoints to explain systemic exposure [9]. Based on these parameters, the ratio of $A_{U} C_{i}$ (AUC of a substrate with an inhibitor) and $\mathrm{AUC}_{0}$ (AUC of a substrate without an inhibitor) over 2 has been used to consider the occurrence of pharmacokinetic drug interaction $[9,30]$. The ratio of an inhibitor concentration in the liver, [I], and $K_{i}$ can determine whether metabolic inhibition in the liver might occur, because sufficient concentration of the inhibitor in the liver, a site containing the majority of CYPs, is a critical factor that causes metabolic inhibition. [I] can be measured in tissue distribution studies at preclinical levels. However, it is impossible to measure [I] in humans. Assuming that systemic exposure is similar to tissue exposure, the $C_{\max }$ of an inhibitor has been used instead of [I] [30]. Unfortunately, the hepatic concentrations or $C_{\max }$ of sauchinone in humans have not been reported yet. Therefore, sauchinone and drug interactions cannot be estimated in humans currently.

Drugs selected in this study have been used to treat metabolic diseases or inflammation. Co-administration of these drugs with S. chinensis containing sauchinone is also clinically probable due to ethnopharmacological use of S. chinensis (e.g., utilization for treatment of beriberi, hyperlipidemia, fever, jaundice, edema, and inflammatory disease; [16]). In rats, sauchinone increased systemic exposure of sibutramine, clopidogrel, or chlorzoxazone, representing the enhanced AUC and $C_{\max }$ values (Table 3). This might be due to inhibition of CYP2B6, CYP2C19/3A, or CYP2E1-mediated clearance of sibutramine, clopidogrel, or chlorzoxazone by sauchinone. Comparable $\mathrm{GI}_{24 \mathrm{~h}}$ values of these drugs between treatments with and without sauchinone indicated that sauchinone did not affect absorption of sibutramine, clopidogrel, or chlorzoxazone (our unpublished data).

\section{Materials and Methods}

\subsection{Chemicals and Reagents}

Sauchinone (over $98 \%$ purity) was provided by Professor Chin Y.-W. (Pharmacognosy Laboratory of Dongguk University, Seoul, Korea) according to the modification of previously reported method [48]. Hydroxybupropion, 4-hydroxymephenytoin, 6-hydroxychlorzoxazone, S-mephenytoin, and pooled human liver microsomes from a mixed pool of 50 donors (HLMs; BD Ultra Pool HLM 50, cat. 452156) were purchased from BD Gentest Co. (Woburn, MA, USA). Acetaminophen, chlorzoxazone, clopidogrel, coumarin, furafylline, $6 \alpha$-hydroxytestosterone, 7-hydroxycoumarin, ketoconazole, 4-methylpyrazole, omeprazole, paroxetine, phenacetin, quinidine, sibutramine, sulfaphenazole, 
testosterone, tetraethylthiuram disulfide, ticlopidine, tienilic acid, tolbutamide, tranylcypromine, verapamil, and reduced form of NADPH (as a tetrasodium salt) were purchased from Sigma-Aldrich (St. Louis, MO, USA). Dextrorphan and 4-hydroxytolbutamide were purchased from Toronto Research Chemicals Inc. (North York, ON, Canada). Bupropion, carbamazepine (internal standard, IS), dextromethorphan, fluvoxamine, fluoxetine, and 8-methoxypsoralen were purchased Wako Co. (Tokyo, Japan). All other chemicals and reagents used were of analytical grade.

\subsection{RI of Sauchinone on CYPs Activities in HLMs}

Sauchinone was dissolved in $\mathrm{N}, \mathrm{N}$-dimethyl formamide and serially diluted with acetonitrile. All CYP selective substrates were dissolved and serially diluted with methanol to give a final organic solvent concentration of $1.0 \%$ (set A) and $0.5 \%$ (set B) in the incubation mixture. Concentrations of CYP selective substrates were used close to their reported Michaelis constant $\left(K_{\mathrm{m}}\right.$, substrate concentration at $1 / 2$ of maximum velocity) values [33] and our unpublished data as shown below: $50 \mu \mathrm{M}$ phenacetin, $5 \mu \mathrm{M}$ coumarin, $50 \mu \mathrm{M}$ bupropion, $100 \mu \mathrm{M}$ tolbutamide, $100 \mu \mathrm{M} S$-mephenytoin, $5 \mu \mathrm{M}$ dextromethorphan, $50 \mu \mathrm{M}$ chlorzoxazone, and $50 \mu \mathrm{M}$ testosterone (substrates of CYP1A2, 2A6, 2B6, 2C9, 2C19, 2D6, 2E1, and 3A4, respectively). Well-known direct inhibitors on the activities of CYP1A2, 2A6, 2B6, 2C9, 2C19, 2D6, 2E1, and 3A4 were fluvoxamine, tranylcypromine, paroxetine, sulfaphenazole, omeprazole, quinidine, 4-methylpyrazole, and ketoconazole, respectively $[49,50]$. Then, $100 \mu \mathrm{L}$ of mixture containing $5 \mu \mathrm{L}$ of HLM ( $1 \mathrm{mg}$ protein), $0.1 \mathrm{M}$ sodium phosphate buffer (pH 7.4), 1 or $0.5 \mu \mathrm{L}$ of substrate cocktail set (set A or B, respectively), and $1 \mu \mathrm{L}$ of inhibitor (sauchinone or a well-known inhibitor for each CYP isoform at $0-300 \mu \mathrm{M}$ ) was incubated at $37^{\circ} \mathrm{C}$ for $5 \mathrm{~min}$ in a thermomixer at $500 \mathrm{rpm}$. The incubation reaction was initiated by adding $2 \mu \mathrm{L}$ of $50 \mathrm{mM}$ NADPH. It was then incubated at $37^{\circ} \mathrm{C}$ for $30 \mathrm{~min}$. The reaction was stopped by adding $50 \mu \mathrm{L}$ of incubation mixture to $100 \mu \mathrm{L}$ of ice-cold acetonitrile containing $20 \mathrm{ng} / \mathrm{mL}$ IS. The samples were then centrifuged at $4{ }^{\circ} \mathrm{C}$ for $10 \mathrm{~min}$ at $12,000 \mathrm{rpm}$. Metabolites of CYP isoforms in supernatants were analyzed by high-performance liquid chromatography-tandem mass spectrometry (HPLC-MS/MS). Half maximal inhibitory concentration $\left(\mathrm{IC}_{50}\right)$ values of sauchinone were estimated for inhibition of each CYP isoform.

\section{3. $K_{i}$ Values of Sauchinone for CYP2B6, 2C19, 2E1, and 3A4 in HLMs}

Based on $\mathrm{IC}_{50}$ values, the $K_{i}$ s of sauchinone for CYP2B6, 2C19, 2E1, and 3A4 were determined. Different concentrations $(20,50$, and $200 \mu \mathrm{M})$ of sauchinone were used. Other procedures were similar to those mentioned above regarding the reversible inhibitory effects of sauchinone. The inhibitory characteristics of sauchinone were initially estimated by nonlinear least squares regression analysis. Its $K_{i}$ values were determined by Dixon plots [51].

\subsection{TDI of Sauchinone on CYP Activities in HLMs}

The $\mathrm{IC}_{50}$ shift assay is the most recommended method to evaluate TDI of sauchinone efficiently and conveniently. Enzymatic activity changes have been usually detected by comparing the presence or absence of a pre-incubation period with an inhibitor during a defined period. Usually, well-known time-dependent inhibitors on CYPs have showed $\mathrm{IC}_{50}$ shifts of $\geq 1.5$-fold with a 30-min pre-incubation (versus 0-min pre-incubation; [29]). This cut-off value of $\mathrm{IC}_{50}$ shift was adjusted to identify the TDI of sauchinone in this study. The well-known time-dependent inhibitors of activities of CYP1A2, 2A6, 2B6, 2C9, 2C19, 2D6, 2E1, and 3A4 were furafylline, 8-methoxypsoralen, ticlopidine, tienilic acid, fluoxetine, paroxetine, disulfiram, and verapamil, respectively.

After $100 \mu \mathrm{L}$ of mixture containing HLM (1 mg protein), $0.1 \mathrm{M}$ sodium phosphate buffer ( $\mathrm{pH} 7.4)$, 1 or $0.5 \mu \mathrm{L}$ of substrate cocktail set (set $\mathrm{A}$ or set B, respectively), and $1 \mu \mathrm{L}$ of inhibitor (sauchinone or a well-known inhibitor at 10 -fold higher concentration than the final incubation concentration at $0-300 \mu \mathrm{M}$ ) was incubated at $37^{\circ} \mathrm{C}$ for $5 \mathrm{~min}$ in a thermomixer at $500 \mathrm{rpm}$, the incubation reaction was initiated by adding $2 \mu \mathrm{L}$ of $50 \mathrm{mM}$ NADPH. Incubation time was then divided into 0 and $30 \mathrm{~min}$. After inactivation incubation for $0 \mathrm{~min}$ or $30 \mathrm{~min}, 100 \mu \mathrm{L}$ of the mixture containing a $10 \mu \mathrm{L}$ aliquot from 
each inactivation incubation tube, $0.1 \mathrm{M}$ sodium phosphate buffer, 1 or $0.5 \mu \mathrm{L}$ of substrate cocktail set (set $\mathrm{A}$ or B), and $2 \mu \mathrm{L}$ of $50 \mathrm{mM} \mathrm{NADPH}$ was incubated for $10 \mathrm{~min}$. These reactions were stopped by adding $50 \mu \mathrm{L}$ of mixture to $100 \mu \mathrm{L}$ of ice-cold acetonitrile containing $20 \mathrm{ng} / \mathrm{mL}$ IS. The sample was centrifuged at $4{ }^{\circ} \mathrm{C}$ for $10 \mathrm{~min}$ at $12,000 \mathrm{rpm}$. Metabolites of CYP isoforms in supernatants were analyzed by HPLC-MS/MS.

\subsection{HPLC-MS/MS Analysis of Metabolites from CYP Substrates, Sibutramine, Clopidogrel, and Chlorzoxazone}

Metabolites from CYP substrates were analyzed using an API4000 triple quadrupole mass spectrometer HPLC-MS/MS system (Applied Biosystems Sciex, Foster City, CA, USA) in multiple reaction monitoring mode with an electrospray ionization interface for positive ions $\left([\mathrm{M}+\mathrm{H}]^{+}\right)$and negative ions $\left(\left[\mathrm{M}-\mathrm{H}^{-}\right)\right.$. Separation was performed on a reversed-phase $\mathrm{C}_{18}$ column (Atlantis $\mathrm{d}-\mathrm{C}_{18}, 2.1 \mathrm{~mm} \times 150 \mathrm{~mm}$ i.d., $3 \mu \mathrm{m}$ particle size; Waters, Dublin, Ireland) maintained at $30^{\circ} \mathrm{C}$. The mobile phase consisted of water containing $0.1 \%$ formic acid (A) and acetonitrile (B) at a flow rate of $0.5 \mathrm{~mL} / \mathrm{min}$. The following gradient elution program used: (1) mobile phase A was set to $100 \%$ at 0 min until $0.1 \mathrm{~min}$; (2) a linear gradient was run to $50 \%$ in $4.0 \mathrm{~min}$. It was held at $50 \%$ until $6.5 \mathrm{~min}$; (3) a linear gradient was run to $0 \%$ in $9.5 \mathrm{~min}$ until $14.0 \mathrm{~min}$; (4) a linear gradient was run to $100 \%$ in $14.3 \mathrm{~min}$ and re-equilibrated for $5.7 \mathrm{~min}$. The total run time was $20 \mathrm{~min}$. Negative-ion mode was used for the analysis of 4-hydroxytolbutamide and 6-hydroxychlorozoxazone.

Turbo ion-spray interface was operated in positive ion mode at an ion source voltage of $5500 \mathrm{~V}$ (negative ion mode $-4500 \mathrm{~V}$ ) and a temperature of $500{ }^{\circ} \mathrm{C}$. Operating conditions optimized by flow injection of a mixture of all analytes were: nebulizing gas flow, $50 \mathrm{~L} / \mathrm{min}$; turbo ion-spray gas flow, $50 \mathrm{~L} / \mathrm{min}$; curtain gas flow, $20 \mathrm{~L} / \mathrm{min}$; collision gas (nitrogen) pressure, 5 Torr; declustering potential, $71.0 \mathrm{eV}$; and entrance potential, $10 \mathrm{eV}$. The $\mathrm{m} / \mathrm{z}$ values (voltage of $\mathrm{CE}$ ) for acetaminophen, 7-hydroxycoumarin, hydroxybupropion, 4-hydroxytolbutamide, 4-hydroxymephenytoin, dextrorphan, 6-hydroxychlorozoxazone, 6 $\alpha$-hydroxytestosterone, and IS were $m / z 152.087 \rightarrow 110.100$ (CE 21 V), $163.072 \rightarrow 107.000(\mathrm{CE} 31 \mathrm{~V}), 257.257 \rightarrow 239.100(\mathrm{CE} 17 \mathrm{~V}), 285.016 \rightarrow 185.800(\mathrm{CE}-26 \mathrm{~V})$, $235.249 \rightarrow 150.000(\mathrm{CE} 27 \mathrm{~V}), 258.178 \rightarrow 157.100(\mathrm{CE} 49 \mathrm{~V}), 184.868 \rightarrow 120.800(\mathrm{CE}-40 \mathrm{~V})$, $305.229 \rightarrow 269.100$ (CE $23 \mathrm{~V})$, and $237.193 \rightarrow 194.100$ (CE $25 \mathrm{~V})$, respectively.

For analysis of sibutramine, a mobile phase was made, consisting of $10 \mathrm{mM}$ ammonium acetate adjusted to $\mathrm{pH} 4$ with acetic acid: acetonitrile $(94: 6, v / v)$ and was eluted at $0.2 \mathrm{~mL} / \mathrm{min}$. The $m / z$ values (voltage of CE) for sibutramine and domperidone (IS) were $280.1 \rightarrow 125.3$ (CE $18 \mathrm{~V}$ ) and $427.3 \rightarrow 175.3$ (CE $19 \mathrm{~V})$, respectively, in positive mode. For analysis of clopidogrel, a mobile phase was consisted of methanol:acetonitrile:distilled water with $0.1 \%$ formic acid $(75: 13: 17, v / v / v)$ and eluted at $0.35 \mathrm{~mL} / \mathrm{min}$. The $\mathrm{m} / \mathrm{z}$ for clopidogrel and ticlopidine (IS) were $322.0 \rightarrow 212.2$ (CE $18 \mathrm{~V}$ ) and $264.3 \rightarrow 154.1$ (CE 17 V), respectively, in positive mode. Chlorzoxazone was analyzed in negative mode with the same mobile phase used for CYP specific metabolites. The $\mathrm{m} / \mathrm{z}$ for chlorzoxazone and carbamazepine (IS) were $167.5 \rightarrow 131.6(\mathrm{CE}-26 \mathrm{~V})$ and $237.1 \rightarrow 194.1$ (CE $-29 \mathrm{~V})$, respectively. Other parameters of mass spectrometers were the same as those used for analysis of metabolites of CYP substrates.

\subsection{Data Analysis for $I C_{50}$ Values}

For RI and TDI screening of sauchinone, CYP-mediated metabolic activities in the presence of sauchinone or well-known inhibitors were expressed as percentages of the corresponding control values. From percentages of control activity versus inhibitor concentrations, a sigmoid shaped curve was fitted to the data and $\mathrm{IC}_{50}$, as an enzyme inhibition parameter, was calculated by fitting the Hill equation to the data using GraphPad Prism 5 (GraphPad Software Inc., San Diego, CA, USA). 


\subsection{Molecular Docking Study}

Based on enzyme inhibition results, interactions of sauchinone with human CYP3A4, CYP2B6, 2C19, and CYP2E1 were analyzed by molecular docking studies. X-ray crystal structures of human CYP3A4 (PDB code: 3UA1; [36]), CYP2B6 (PDB code: 3IBD; [9]), CYP2C19 (PDB code: 4GQS; [42]), and CYP2E1 (PDB code: 3GPH; [45]) were retrieved from Research Collaboratory for Structural Bioinformatics (RCSB) Protein Databank (https:/ / www.rcsb.org/). Discovery Studio 2017 R2 (Dassault Systèmes BIOVIA, San Diego, CA, USA) was employed to create the sauchinone structure. It was also used for energy minimization. AutoDock 4.2.6 software (Molecular Graphics Laboratory, La Jolla, CA, USA) was used to perform molecular docking [52]). Both protein and ligand structures were processed prior to molecular docking studies using AutoDock Tools 1.5.6 [53]. For each CYP, the AutoGrid program was used to create a grid box around co-crystallized ligand to cover active site of the protein. Grid of size $40 \times 40 \times 40 \AA^{3}$ with $0.375 \AA$ spacing was centered on co-crystallized ligand of each CYP. Docking simulations were performed using the Lamarckian genetic algorithm (LGA) [54]. A total of 100 runs along with $25 \times 10^{5}$ energy evaluations and 27,000 iterations were carried out. Default values were used for other parameters. Docked poses were chosen based on scoring functions and protein-ligand interactions. Discovery Studio 2017 R2 was used to visualize binding interactions.

\subsection{Animals}

Protocols for animal studies were approved by the Institutional Animal Care and Use Committee of Dongguk University-Seoul, Seoul, South Korea (2014-DGU-04). Male ICR mice (5 weeks old, weight of 20-25 g) were purchased from the Charles River Company Korea (Orient, Seoul, Korea). All mice were maintained under controlled room temperature, humidity, and light (12/12 h light/dark cycle). They were provided free access to food and water. These mice were allowed to acclimate to these conditions for three days prior to inclusion in the experiments.

\subsection{Drug Interaction of Sibutramine, Clopidogrel, or Chlorzoxazone with Sauchinone in Mice}

To investigate the inhibitory effect of sauchinone on CYP2B6, 2C19, 2E1, or 3A4-mediated metabolism, pharmacokinetic interactions of drugs (sibutramine, clopidogrel, or chlorzoxazone) with sauchinone were examined in mice. Sibutramine, clopidogrel, and chlorzoxazone were chosen as representative drugs mainly metabolized by CYP2B6, 2C19/3A4, and 2E1, respectively [24-26,47].

Surgical procedures for mice were conducted under tiletamine $\mathrm{HCl}$ and zolazepam $\mathrm{HCl}$ anesthesia by intramuscular injection. The carotid artery (for blood sampling) cannulation was carried out using catheters (BASi, West Lafayette, IN, USA). Drug administration and blood sampling were performed at $5 \mathrm{~h}$ after surgery [55]. Thirty minutes after oral administration of $100 \mathrm{mg} / \mathrm{kg}$ sauchinone, $1 \mathrm{mg} / \mathrm{kg}$ sibutramine was administered intraperitoneally to mice. Blood samples were collected via the carotid artery at $0,5,15,30,60,90,120,240,360$, and $480 \mathrm{~min}$ after administration of sibutramine. Ten $\mu \mathrm{L}$ of blood was collected into a micro-vial containing $50 \mu \mathrm{L}$ of 12.5 units $/ \mathrm{mL}$ heparinized saline using micro-sampling system. After centrifugation of each micro-vial, $50 \mu \mathrm{L}$ of plasma with heparinized-saline was collected from the supernatant and analyzed by HPLC-MS/MS. Instead of sibutramine, $10 \mathrm{mg} / \mathrm{kg}$ clopidogrel or $10 \mathrm{mg} / \mathrm{kg}$ chlorzoxazone was administered thirty minutes after oral administration of $100 \mathrm{mg} / \mathrm{kg}$ sauchinone or vehicle. Other procedures were the same as those used for the sibutramine pharmacokinetic study.

After analyzing sibutramine, clopidogrel, or chlorzoxazone concentrations in plasma by HPLC-MS/MS, pharmacokinetic parameters were calculated as follows. AUC was calculated using the trapezoidal rule method. Standard methods [56] were used to calculate pharmacokinetic parameters using non-compartmental analysis (WinNonlin 2.1; Pharmasight Corp., Mountain View, CA, USA). $C_{\max }$ and $T_{\max }$ were read reversibly from extrapolated data. 


\section{Conclusions}

Our results demonstrated for the first time that sauchinone has potential to inhibit CYP2B6, 2C19, 2E1, and/or 3A4-mediated metabolism noncompetitively. This could cause pharmacokinetic interactions between drugs and sauchinone. The inhibitory effects of sauchinone on CYP2B6, 2E1, and 3A4 were time-dependent. Molecular docking studies identified interacting residues of CYP2B6, 2C19, 2E1, and 3A4 with sauchinone, supporting the inhibitory potential of sauchinone on these CYP isoforms. At preclinical levels, sauchinone inhibited the metabolic clearance of drugs such as sibutramine, clopidogrel, and chlorzoxazone. Sauchinone and drug interactions might cause unwanted effects. Therefore, more attention is needed when using herb-drug combination therapies.

Acknowledgments: This study was supported by a grant from the National Research Foundation of Korea (NRF) grant funded by the Korea government (MSIT) (NRF-2016R1C1B2010849).

Author Contributions: Young-Won Chin and Young Hee Choi conceived and designed the experiments; Eun Chae Gong, Satya Chea and Anand Balupuri performed the experiments; Eun Chae Gong and Young Hee Choi analyzed the data; Eun Chae Gong, Nam Sook Kang and Young-Won Chin contributed reagents/materials/analysis tools; Nam Sook Kang and Young Hee Choi wrote the paper.

Conflicts of Interest: The authors declare no conflict of interest.

\section{References}

1. Choi, Y.H.; Chin, Y.-W.; Kim, Y.G. Herb-drug interactions: Focus on metabolic enzymes and transporters. Arch. Pharm. Res. 2011, 34, 1843-1863. [CrossRef] [PubMed]

2. Izzo, A.A.; Ernst, E. Interactions between herbal medicines and prescribed drugs: An updated systemic review. Drugs 2009, 69, 1777-1798. [CrossRef] [PubMed]

3. Niu, L.; Ding, L.; Lu, C.; Zuo, F.; Yao, K.; Wu, S.; Li, W.; Yang, D.; Xu, X. Flavokawain A inhibits cytochrome P450 in in vitro metabolic and inhibitory investigations. J. Ethnopharmacol. 2016, 191, 350-359. [CrossRef] [PubMed]

4. Haque, M.; Leong, K.H.; Lo, Y.L.; Awang, K.; Nagoor, N.H. In vitro inhibitory mechanisms and molecular docking of 1'-S-1'-acetoxychavicol acetate on human cytochrome P450 enzymes. Phytomedicine 2017, 31, 1-9. [CrossRef] [PubMed]

5. Meng, Q.; Liu, K. Pharmacokinetic interactions between herbal medicines and prescribed drugs: Focus on drug metabolic enzymes and transporters. Curr. Drug Metab. 2014, 15, 791-807. [CrossRef] [PubMed]

6. Vanden Brink, B.M.; Isoherranen, M. The role of metabolites in predicting drug-drug interactions: Focus on irreversible cytochrome P450 inhibition. Curr. Opin. Drug Discov. Dev. 2010, 13, 66-77.

7. Wang, B.; Yang, S.; Hu, J.; Li, Y. Mulrifaced interation of the traditional chinese medical herb Schisandra chinesis with cytochrome P450-mediated drug metabolism in rats. J. Ethnopharmacol. 2014, 155, 1473-1482. [CrossRef] [PubMed]

8. Wu, J.J; Ai, C.Z.; Liu, Y.; Zhang, Y.Y.; Jiang, M.; Fan, X.R.; Lv, A.P.; Yang, L. Interactions between phytochemicals from traditional Chinese medicines and human cytochrome P450 enzymes. Curr. Drug Metab. 2012, 13, 599-614. [CrossRef] [PubMed]

9. Goey, A.K.L.; Mooiman, K.D.; Beijnen, J.H.; Schellens, J.H.M.; Meijerman, I. Relevance of in vitro and clinical data for predicting CYP3A4-mediated herb-drug interactions in cancer patients. Caner Treat. Rev. 2013, 39, 773-783. [CrossRef] [PubMed]

10. Hermann, R.; von Richter, O. Clinical evidence of herbal drugs as perpetrators of pharmacokinetic drug interactions. Planta Med. 2012, 78, 1458-1477. [CrossRef] [PubMed]

11. Lau, W.C.; Welch, T.C.; Shields, T.; Rubenfire, M.; Tantry, U.S.; Gurbel, P.A. The effect of St John's Wort on the pharmacodynamic response of clopidogrel in hyporesponsive volunteers and patients: Increased platelet inhibition by enhancement of CYP3A4 metabolic activity. J. Cardiovasc. Pharmacol. 2011, 57, 86-93. [CrossRef] [PubMed]

12. Srinivas, N.R. Cranberry juice ingestion and clinical drug-drug interaction potentials: Review of case studies and perspectives. J. Pharm. Sci. 2013, 16, 289-303. [CrossRef] 
13. Stolbach, A.; Paziana, K.; Heverling, H.; Pham, P. A review of the toxicity of HIV medications II: Interactions with drugs and complementary and alternative medicine products. J. Med. Toxicol. 2015, 11, 326-341. [CrossRef] [PubMed]

14. Grimm, S.W.; Einolf, H.J.; Hall, S.D.; He, K.; Lim, H.K.; Ling, K.H.; Lu, C.; Nomeir, A.A.; Seibert, E.; Skordos, K.W.; et al. The conduct of in vitro studies to address time-dependent inhibition of drug-metabolizing enzymes: A prospective of the pharmaceutical research and manufacturers of America. Drug Metab. Dispos. 2009, 37, 1355-1370. [CrossRef] [PubMed]

15. Food and Drug Adminstration. Guidance for Industry-Drug Interaction Studies-Study Design, Data Analysis, Implications for Dosing and Labeling; Food and Drug Adminstration: Silver Spring, MD, USA, 2012.

16. Chung, B.S.; Shin, M.G. Dictionary of Korean Folk Medicine; Young Lim Sa: Seoul, Korea, 1990; pp. 813-814.

17. Kim, H.-B.; Hwang, E.-S.; Choi, G.-Y.; Lee, S.; Park, T.-S.; Lee, C.-W.; Lee, E.-S.; Kim, Y.-C.; Kim, S.S.; Lee, S.-O.; et al. ESP-102, a combined herbal extract of Angelica gigas, Saururus chinensis, and Schisandra chinensis, changes synaptic plasticity and attenuates scopolamine-induced memory impairment in rat hippocampus tissue. Evid.-Based Complement. Altern. Med. 2016, 2016. [CrossRef] [PubMed]

18. Kim, Y.W.; Kim, Y.M.; Yang, Y.M.; Kim, T.H.; Hwang, S.J.; Lee, J.R.; Kim, S.C.; Kim, S.G. Inhibition of SREBP-1c-mediated hepatic steatosis and oxidative stress by sauchinone, an AMPK-activating lignan in saururus chinensis. Free Radic. Biol. Med. 2010, 48, 567-578. [CrossRef] [PubMed]

19. Joo, H.J.; Kang, M.J.; Seo, T.J.; Kim, H.A.; Yoo, S.J.; Lee, S.K.; Lim, H.J.; Byun, B.H.; Kim, J.I. The hypoglycemic effect of Saururus chinensis Baill in animal models of diabetes mellitus. Food Sci. Biotechnol. 2006, 15, 413-417.

20. Jung, M.H.; Song, M.C.; Bae, K.; Kim, H.S.; Kim, S.H.; Sung, S.H.; Ye, S.K.; Lee, K.H.; Yun, Y.P.; Kim, T.J. Sauchinone attenuated oxidative stress-induced skeletal muscle myoblast damage through the down-regulation of ceramide. Biol. Pharm. Bull. 2011, 34, 575-579. [CrossRef] [PubMed]

21. Yu, M.H.; Im, H.G.; Lee, J.W.; Bo, M.H.; Kim, H.J.; Kim, S.K.; Chung, S.K.; Lee, I.S. Effects of ethanol extract from Saururus chinensis (Bour.) Baill on lipid and antioxidant metabolisms in rats fed a high-fat diet. Nat. Prod. Res. 2008, 22, 275-283. [CrossRef] [PubMed]

22. Yun, Y.R.; Kim, M.J.; Kwon, M.J.; Kim, H.J.; Song, Y.B.; Song, K.B.; Song, Y.O. Lipid-lowering effect of hot water-soluble extracts of Saururus chinensis Bail on rats fed high fat diets. J. Med. Food 2007, 10, 316-322. [CrossRef] [PubMed]

23. Kim, Y.J.; Han, S.Y.; Seo, J.S.; Chin, Y.-W.; Choi, Y.H. Pharmacokinetics, tissue distribution, and tentative metabolite identification of sauchinone in mice by microsampling and HPLC-MS/MS methods. Biol. Pharm. Bull. 2015, 38, 218-227. [CrossRef] [PubMed]

24. Gao, N.; Zou, D.; Qiao, H.L. Concentration-dependent inhibitory effect of baicalin on the plasma protein binding and metabolism of chlorzoxazone, a CYP2E1 probe substrate, in rats in vitro and in vivo. PLoS ONE 2013, 8, e53038. [CrossRef] [PubMed]

25. Noh, K.; Bae, K.; Min, B.; Kim, E.; Kwon, K.I.; Jeong, T.; Kang, W. Enantioselective pharmacokinetics of sibutramine in rat. Arch. Pharm. Res. 2010, 33, 267-273. [CrossRef] [PubMed]

26. Zahno, A.; Brecht, K.; Bodmer, M.; Bur, D.; Tsakiris, D.A.; Krähenbühl, S. Effects of drug interactions on biotransformation and antiplatelet effect of clopidogrel in vitro. Br. J. Pharmacol. 2010, 161, 393-404. [CrossRef] [PubMed]

27. Chen, A.; Zhou, X.; Tang, S.; Liu, M.; Wang, X. Evaluation of the inhibition potential of plumbagin aginst cytochrome P450 using LC-MS/MS and cocktail approach. Sci. Rep. 2016, 6, 28482. [CrossRef] [PubMed]

28. Fowler, S.; Zhang, H. In vitro evaluation of reversible and irreversible cytochrome P450 inhibition: Current status on methodologies and their utility for predicting drug-drug interactions. AAPS J. 2008, 10, 410-424. [CrossRef] [PubMed]

29. Berry, L.M.; Zhao, Z. An examination of $\mathrm{IC}_{50}$ and $\mathrm{IC}_{50}$-shift experiments in assessing time-dependent inhibition of CYP3A4, CYP2D6, and CYP2C9 in human liver microsomes. Drug Metab. Lett. 2008, 2, 51-59. [CrossRef] [PubMed]

30. Filppula, A.M.; Neuvonen, P.J.; Backman, J.T. In vitro assessment of time-dependent inhibitory effects on CYP2C8 and CYP3A activity by fourteen protein kinase inhibitors. Drug Metab. Dispos. 2014, 42, 1202-1209. [CrossRef] [PubMed]

31. Sridar, C.; Goosen, T.C.; Anderw Williams, K.J.; Hollenberg, P.F. Silybin inactivates cytochromes P450 3A4 and 2C9 and inhibits major hepatic glucuronosyltransferases. Drug Metab. Dispos. 2004, 32, 587-594. [CrossRef] [PubMed] 
32. Thomford, N.E.; Dzobo, K.; Chopera, D.; Wonkam, A.; Maroyi, A.; Blackhurst, D.; Dandara, C. In vitro reversible and time-dependent CYP450 inhibition profiles of medicinal herbal plant extracts Newbouldia laevis and Cassia abbreviata: Implications for herb-drug interactions. Molecules 2016, 21, 891. [CrossRef] [PubMed]

33. Lee, K.S.; Kim, S.K. Direct and metabolism-dependent cytochrome P450 inhibition assays for evaluating drug-drug interactions. J. Appl. Toxicol. 2013, 33, 100-108. [CrossRef] [PubMed]

34. Ekroos, M.; Sjögren, T. Structural basis for ligand promiscuity in cytochrome P450 3A4. Proc. Natl. Acad. Sci. USA 2006, 103, 13682-13687. [CrossRef] [PubMed]

35. Qiu, J.-X.; Zhou, Z.-W.; He, Z.-X.; Zhang, X.; Zhou, S.-F.; Zhu, S. Estimation of the binding modes with important human cytochrome P450 enzymes, drug interaction potential, pharmacokinetics, and hepatotoxicity of ginger components using molecular docking, computational, and pharmacokinetic modeling studies. Drug Des. Dev. Ther. 2015, 9, 841-866. [CrossRef]

36. Sevrioukova, I.F.; Poulos, T.L. Structural and mechanistic insights into the interaction of cytochrome P4503A4 with bromoergocryptine, a type I ligand. J. Biol. Chem. 2012, 287, 3510-3517. [CrossRef] [PubMed]

37. Zhou, X.; Wang, Y.; Hu, T.; Or, P.M.; Wong, J.; Kwan, Y.W.; Wan, D.C.; Hoi, P.M.; Lai, P.B.; Yeung, J.H. Enzyme kinetic and molecular docking studies for the inhibitions of miltirone on major human cytochrome P450 isozymes. Phytomedicine 2013, 20, 367-374. [CrossRef] [PubMed]

38. Gay, S.C.; Shah, M.B.; Talakad, J.C.; Maekawa, K.; Roberts, A.G.; Wilderman, P.R.; Sun, L.; Yang, J.Y.; Huelga, S.C.; Hong, W.-X. Crystal structure of a cytochrome P450 2B6 genetic variant in complex with the inhibitor 4-(4-chlorophenyl) imidazole at 2.0-Å resolution. Mol. Pharmacol. 2010, 77, 529-538. [CrossRef] [PubMed]

39. Kobayashi, K.; Takahashi, O.; Hiratsuka, M.; Yamaotsu, N.; Hirono, S.; Watanabe, Y.; Oda, A. Evaluation of influence of single nucleotide polymorphisms in cytochrome P450 $2 \mathrm{~B} 6$ on substrate recognition using computational docking and molecular dynamics simulation. PLoS ONE 2014, 9, e96789. [CrossRef] [PubMed]

40. Niu, R.-J.; Zheng, Q.-C.; Zhang, J.-L.; Zhang, H.-X. Analysis of clinically relevant substrates of CYP2B6 enzyme by computational methods. J. Mol. Model. 2011, 17, 2839-2846. [CrossRef] [PubMed]

41. Foti, R.S.; Rock, D.A.; Han, X.; Flowers, R.A.; Wienkers, L.C.; Wahlstrom, J.L. Ligand-based design of a potent and selective inhibitor of cytochrome P450 2C19. J. Med. Chem. 2012, 55, 1205-1214. [CrossRef] [PubMed]

42. Reynald, R.L.; Sansen, S.; Stout, C.D.; Johnson, E.F. Structural Characterization of Human Cytochrome P450 2C19 active site differences between P450s 2C8, 2C9, and 2C19. J. Biol. Chem. 2012, 287, 44581-44591. [CrossRef] [PubMed]

43. Cui, Y.L.; Zheng, Q.C.; Zhang, J.L.; Zhang, H.X. Molecular basis of the recognition of arachidonic acid by cytochrome P450 2E1 along major access tunnel. Biopolymers 2015, 103, 53-66. [CrossRef] [PubMed]

44. Levy, J.W.; Hartman, J.H.; Perry, M.D.; Miller, G.P. Structural basis for cooperative binding of azoles to CYP2E1 as interpreted through guided molecular dynamics simulations. J. Mol. Graph. Model. 2015, 56, 43-52. [CrossRef] [PubMed]

45. Porubsky, P.R.; Battaile, K.P.; Scott, E.E. Human cytochrome P450 2E1 structures with fatty acid analogs reveal a previously unobserved binding mode. J. Biol. Chem. 2010, 285, 22282-22290. [CrossRef] [PubMed]

46. Saxena, A.; Tripathi, K.P.; Roy, S.; Khan, F.; Sharma, A. Pharmacovigilance: Effects of herbal components on human drugs interactions involving Cytochrome P450. Bioinformation 2008, 3, 198-204. [CrossRef] [PubMed]

47. Chen, X.; Jin, J.; Chen, Y.; Peng, L.; Zhong, G.; Li, J.; Bi, H.; Cai, Y.; Huang, M. Effect of scutellarin on the metabolism and pharmacokinetics of clopidogrel in rats. Biopharm. Drug Dispos. 2015, 36, 64-68. [CrossRef] [PubMed]

48. You, B.H.; Gong, E.C.; Choi, Y.H. Inhibitory Effect of sauchinone on UDP-glucuronosyltransferase (UGT) 2B7 activity. Molecules 2018, 23, 366. [CrossRef] [PubMed]

49. Miia, T.; Uusitalo, J.; Jalonen, J.; Pelkonen, O. Multiple P450 substrates in a single run: Rapid and comprehensive in vitro interaction assay. Eur. J. Pharm. Sci. 2005, 24, 123-132. [CrossRef]

50. Pelkonen, O.; Turpeinen, M.; Hakkola, J.; Honkakoski, P.; Hukkanen, J.; Roaunio, H. Inhibition and induction of human cytochrome P450 enzymes: Current status. Arch. Toxicol. 2008, 82, 667-715. [CrossRef] [PubMed]

51. Segel, I.H. Enzyme Kinetics: Behavior and Analysis of Rapid Equilibrium and Steady State Systems; Wiley: New York, NY, USA, 1975.

52. Morris, G.M.; Huey, R.; Lindstrom, W.; Sanner, M.F.; Belew, R.K.; Goodsell, D.S.; Olson, A.J. AutoDock4 and AutoDockTools4: Automated docking with selective receptor flexibility. J. Comput. Chem. 2009, 30, 2785-2791. [CrossRef] [PubMed] 
53. Sanner, M.F. Python: A programming language for software integration and development. J. Mol. Graph. Model. 1999, 17, 57-61. [PubMed]

54. Morris, G.M.; Goodsell, D.S.; Halliday, R.S.; Huey, R.; Hart, W.E.; Belew, R.K.; Olson, A.J. Automated docking using a Lamarckian genetic algorithm and an empirical binding free energy function. J. Comput. Chem. 1998, 19, 1639-1662. [CrossRef]

55. Han, S.Y.; Kim, Y.J.; Kim, Y.M.; Chin, Y.-W.; Choi, Y.H. Absorption, tissue distribution, tissue metabolism and safety of $\alpha$-mangostin in mangosteen extract using mouse models. Food Chem. Toxicol. 2014, 66, 140-146. [CrossRef]

56. Gibaldi, M.; Perrier, D. General derivation of the equation for time to reach a certain fraction of steady state. J. Pharm. Sci. 1982, 71, 474-475.

Sample Availability: Samples of the compounds are not available from the authors.

(C) 2018 by the authors. Licensee MDPI, Basel, Switzerland. This article is an open access article distributed under the terms and conditions of the Creative Commons Attribution (CC BY) license (http:/ / creativecommons.org/licenses/by/4.0/). 